\title{
COMPATIBLE STEM VOLUME AND TAPER EQUATIONS FOR FIVE MAJOR TREE SPECIES IN NORTHEAST CHINA
}

\author{
HuSSAIN, A. - ShAHZAD, M. K. - XIN, S. D. - JiANG, L. C. \\ Key Laboratory of Sustainable Forest Ecosystem Management-Ministry of Education, School of \\ Forestry, Northeast Forestry University, Harbin 150040, China \\ *Corresponding author \\ e-mail: jlcnefu@126.com
}

(Received $18^{\text {th }}$ Feb 2020; accepted $9^{\text {th }}$ Jul 2020)

\begin{abstract}
Compatible segmented taper and volume equations were developed for Dahurian larch, Korean spruce, Manchurian fir, planted Dahurian larch and Mongolian pine in northeast China. The model form developed by Max and Burkhart (1976) was fitted to the data of 720 sample trees. The data was randomly split into two sets for each species: $80 \%$ of total data was used for model fitting, and $20 \%$ of total data was reserved for model validation. The proposed equation provided good results for the whole tree and different stem sections. Mean prediction errors for diameter and volume were less than $1.9 \mathrm{~cm}$ and $0.005 \mathrm{~m}^{3}$, respectively. The recommended model provided adequate diameter and merchantable volume estimates against ten relative height classes, examined for each species. Additionally, the model's estimates were superior to the existing volume tables for these commercial species, particularly for Korean spruce, Manchurian fir, and planted Dahurian larch.
\end{abstract}

Keywords: segmented models, taper and volume, Dahurian larch, Korean spruce, Manchurian fir, Mongolian pine

\section{Introduction}

China has assigned a strategic position to forestry development and ecological improvement, being pivotal factors in the sustainable development of the society and economy. A significant increase of $8.94 \%$ has been achieved in the total forest cover during the past forty years. However, sustainable forestry development remains a rigorous challenge to bridge supply and demand conflicts and meet other national and international commitments (Jia and Qu, 2011; Zeng et al., 2015). At the same time, plenty of room for improvement is available in terms of multiple products and services of the forests. Therefore, sustainable forest management is declared as a core objective of the forestry research for which accurate predictions of the standing volume are a prerequisite.

Distributed over an area of 32.71 million hectares with 28.18 billion $\mathrm{m}^{3}$ of standing volume, northeast China is the largest forested area in the country (Zeng et al., 2015). It is recognized as a national base of wood products and a region of ecological significance. This region covers $30 \%$ of the total area, and almost half of the national ecosystem carbon is stored in these forests (Zhang et al., 2018).

Natural and planted Dahurian larch (Larix gmelinii), Korean spruce (Picea koraiensis), Manchurian fir (Abies nephrolepis), and planted Mongolian pine (Pinus sylvestris) are dominant commercial tree species in NE China. The forests of Larix gmelinii, Picea koraiensis, and Abies nephrolepis, and plantations of Larix gmelinii and Pinus sylvestris occupy 10.6 million ha, 4.3 million ha, 3.1 million ha, 2.8 million ha, and 0.2 million ha area, respectively. The corresponding standing volume of these species is 955.2 million $\mathrm{m}^{3}$, 1001.6 million $\mathrm{m}^{3}, 1135.6$ million $\mathrm{m}^{3}, 163.9$ million $\mathrm{m}^{3}$, and 13.5 million $\mathrm{m}^{3}$ (Chinese Ministry of Forestry, 2009). Larix gmelinii is the dominant tree 
species of Larix forests and covers $55 \%$ of the total area, $75 \%$ of total volume (Zhou et al., 2002). Picea koraiensis is the leading species of Picea forests with Abies nephrolepis as a major associate in NE China.

China has the largest forest plantations in the world; over an area of 79 million ha, that amounts to 25\% of the world's total (FAO, 2015; Payn et al., 2015). Dahurian larch is generally planted after fire incidents and logging due to its fast growth and cold tolerance. The growth rate of these plantations is an important indicator to assess the forest recovery process and carbon sequestration potential (Jia and Zhou, 2018). Mongolian pine (Pinus sylvestris L. var. mongolica Litv.), a geographical variety of Scots pine (Pinus sylvestris L.) is highly tolerant to cold, drought, and soil infertility. It has been widely planted in the Three-North (north, northeast, northwest) project of China for timber production, windbreaks, and soil and water conservation (Zhang et al., 2019). Measurement tools are required for the sustainable management of these species that should allow for the industrial and ecological advances in Chinese forestry.

As a measurement tool, taper models are an essential component in prevailing forest management and planning systems (Heidarsson and Pukkala, 2011). Generally, taper models use the diameter at breast height, total height, and height above ground as independent variables, since these measurements can be easily recorded during routine forest inventories (Brooks et al., 2008). Such models can estimate (i) diameter at any height; (ii) total volume; (iii) merchantable volume and merchantable height; (iv) and volume of a log from any section of the stem (Kozak, 2004). Additionally, taper models are utilized in timber quality studies, decisions support systems, assessing the impact of silvicultural treatment on stem taper, and in the modelling of carbon allocation in different stem sections (Deleuze and Houllier, 2002; Ikonen et al., 2003; Younger et al., 2008).

Taper models have been a topic of interest in forest mensuration and management studies for over a century (Fang and Bailey, 1999). Newnham (1988) has described two reasons that bring taper models into topicality. Firstly, no single theory can satisfactorily explain all types of stem forms. Secondly, taper models are flexible tools for total and merchantable volume estimates that can comply with the changes in market trends and product classification. Practically, this flexibility of taper models keeps them under perpetual studies.

Numerous taper models of different forms have been developed over the years. A detailed discussion is available in the literature regarding the types, evolution, and comparison of these models (Rojo et al., 2005; Diéguez-Aranda et al., 2006; Sakici et al., 2008; Crecente-Campo et al., 2009; Özcelik and Crecente-Campo, 2016; Burkhart et al., 2019). The approaches of variable form taper equations and segmented taper equations have substantiated their superiority in different studies, e.g. (Barrio Anta et al., 2007; Li and Weiskittel, 2010; Schröder et al., 2014; Lumbres et al., 2016; Özcelik and Dirican, 2017; Sakici and Ozdemir, 2018). Generally, variable form taper functions provide the lowest range of local bias and maximum precision. However, they are unable to calculate total stem volume or log volume and merchantable height. Numerical integration and iteration procedure is required to calculate these variables. Alternatively, segmented taper functions can be integrated to calculate volume, and merchantable heights can be obtained directly from the equation (Kozak and Smith, 1993).

The integration of a taper equation can provide volume estimates to any merchantability limit, as well as to the total tree height. Taper and volume equations are compatible when total volume calculated by the integration of a taper equation is identical to the results of the volume equation (Demaerschalk, 1972). The primary benefit of a 
compatible taper volume system is to achieve consistent results from both taper and volume equations (Burkhart and Tomé, 2012; Özcelik and Göceri, 2015).

There are some references to taper and volume studies of Pinus sylvestris (natural forests) in Europe, the USA, and Turkey (e.g., Laasasenaho, 1982; Westfall and Scott, 2010; Özcelik and Brooks, 2012). In China, Larix gmelinii, Picea koraiensis, Abies nephrolepis, and Pinus sylvestris L. var. mongolica have been studied, but the investigations were focussed on biomass and climate change (Zhou et al., 2002; Wang et al., 2012, 2018; Dong et al., 2014; Ma et al., 2014). A segmented taper equation was also presented for planted Larix gmelinii in NE China (Jiang and Liu, 2011). However, compatible taper and volume equations are yet to be developed for these dominant tree species in NE China.

At present, volume estimation is based on the volume tables, which were developed more than three decades ago (Heilongjiang Forest Bureau, 1981). The species under analysis provide timber for building logs, railway sleepers, construction, shipbuilding, and plywood and veneer. Other uses include soundboards in the musical instrument, boxes, and raw materials for the pulp industry. The versatility in their uses requires accurate estimates of the diameters and volumes to different merchantability limits. The conventional volume tables are no longer adequate for volume estimation in fluctuating market trends and product specifications.

The objective of this study was to develop a volume equation that can correctly estimate the tree volume to any merchantable size. A widely recognized and flexible taper equation presented by Max and Burkhart (1976) was evaluated for five commercial tree species of NE China. The total volume estimates, obtained from the proposed equation, were also compared with the prevailing volume tables.

\section{Material and methods}

\section{Study area}

This study was conducted at Lilin forest farm $\left(129^{\circ} 15^{\prime}-129^{\circ} 30^{\prime} \mathrm{E}, 48^{\circ} 74^{\prime}-49^{\circ} 9^{\prime} \mathrm{N}\right)$ covering an area of covering an area of $8128 \mathrm{hm}^{2}$ and Jinsha forest farm $\left(130^{\circ} 06^{\prime}-131^{\circ} 58^{\prime} \mathrm{E}, 45^{\circ} 16^{\prime}-46^{\circ} 37^{\prime} \mathrm{N}\right)$, with an area of $6651 \mathrm{hm}^{2}$ located in Wuying forest bureau and Qitaihe City, respectively in Heilongjiang province, NE China. The sample trees of Dahurian larch, Korean spruce, and Manchurian fir were selected from the natural stands in the Lilin forest farm. It falls in the cold temperate forest with a continental monsoon climate. The mean annual precipitation fluctuates from 550 to $600 \mathrm{~mm}$, and the mean annual temperature ranges from $0^{\circ} \mathrm{C}$ to $2^{\circ} \mathrm{C}$. The predominant forest types are Larix gmelinii, Picea koraiensis, Abies nephrolepis, and deciduous broadleaf mixed forest (Tan et al., 2007).

The sample trees of planted Dahurian larch and Mongolian pine were selected from the Jinsha forest farm (Figure 1). This area is located in the middle temperate humid climate zone, with four distinct seasons and uneven distribution of precipitation in each season. The mean annual precipitation is $549 \mathrm{~mm}$, and the mean annual temperature is $4.0^{\circ} \mathrm{C}$. The typical soil type of the study area is mainly dark brown soil (Burger and Shidong, 1988).

A sample of 770 trees was collected from natural stands and plantations, covering the existing range of stand densities, conditions, and sites. Diameter at breast height (D) was measured to the nearest $0.1 \mathrm{~cm}$. Later, the trees were felled to measure the total height $(\mathrm{H})$ to the nearest $0.1 \mathrm{~m}$. The diameter outside bark (d) was measured at the heights (h) of 0.3 , 
$0.6,1,1.3,2,3 \mathrm{~m}$, and then at an interval of $1 \mathrm{~m}$ for the rest of the stem. The data were randomly split into two sets for each species: $80 \%$ of total data (617 sample trees) for model fitting and $20 \%$ of total data (153 sample trees) for model validation. Descriptive statistics for both data sets are shown in Tables 1 and 2. The overlapping bolts method was used to calculate the actual volume of each bolt and tree (Bailey, 1995).
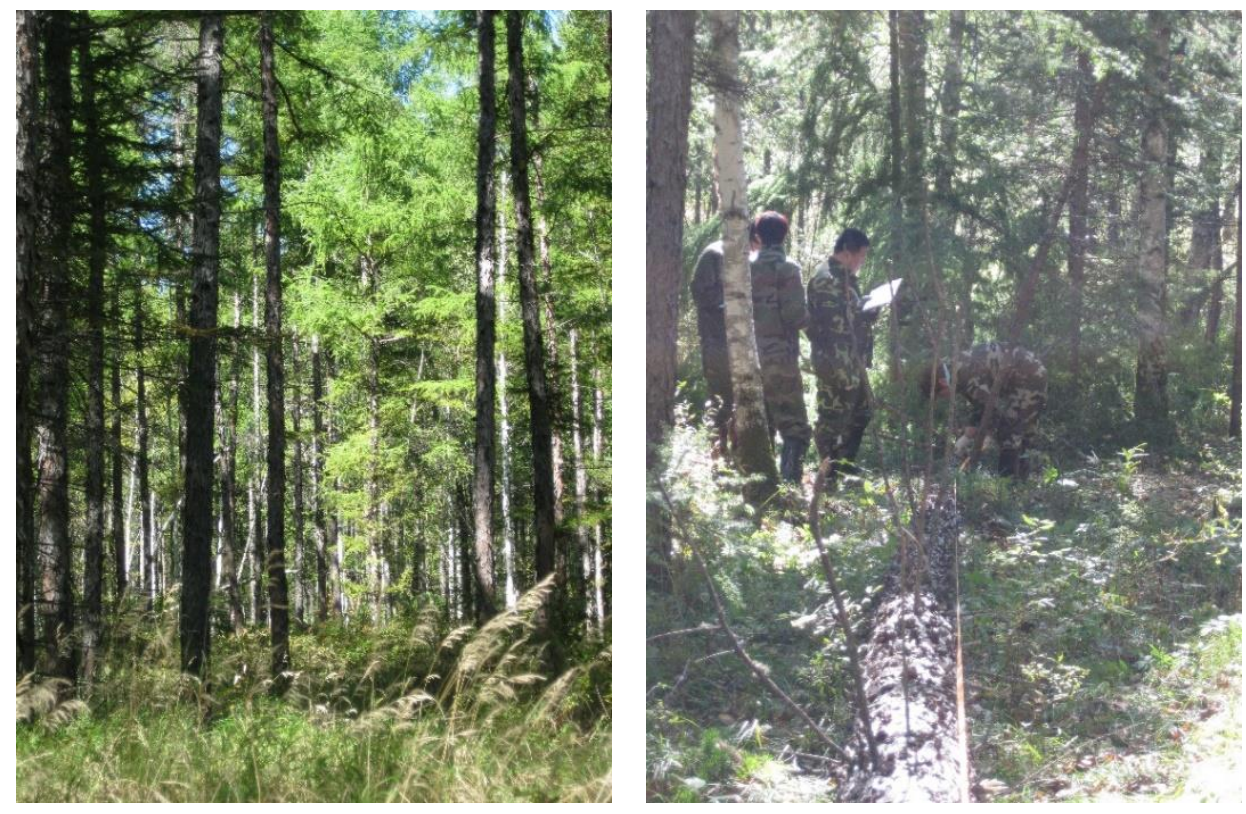

Figure 1. Image of Lilin forest farm and Jinsha forest farm Data collection

Table 1. Fitting data summary statistics for five commercial tree species in NE China

\begin{tabular}{|c|c|c|c|c|c|}
\hline Natural species & Variable & Mean & SD & Minimum & Maximum \\
\hline \multirow{4}{*}{$\begin{array}{l}\text { Dahurian larch } \\
(\mathrm{n}=110 \text { trees })\end{array}$} & $D(\mathrm{~cm})$ & 24.37 & 5.64 & 8.6 & 40.2 \\
\hline & $H(\mathrm{~m})$ & 18.67 & 2.57 & 8.9 & 24.6 \\
\hline & $d(\mathrm{~cm})$ & 17.61 & 8.89 & 1.0 & 50.4 \\
\hline & $h(\mathrm{~m})$ & 7.90 & 6.03 & 0.3 & 24.0 \\
\hline \multirow{4}{*}{$\begin{array}{l}\text { Korean spruce } \\
(\mathrm{n}=124 \text { trees })\end{array}$} & $D(\mathrm{~cm})$ & 29.38 & 6.89 & 9.1 & 49.5 \\
\hline & $H(\mathrm{~m})$ & 21.59 & 3.90 & 6.8 & 30.7 \\
\hline & $d(\mathrm{~cm})$ & 22.37 & 9.65 & 1.2 & 58.6 \\
\hline & $h(\mathrm{~m})$ & 9.32 & 7.10 & 0.3 & 30.0 \\
\hline \multirow{4}{*}{$\begin{array}{l}\text { Manchurian fir } \\
(\mathrm{n}=145 \text { trees })\end{array}$} & $D(\mathrm{~cm})$ & 25.49 & 5.92 & 5.5 & 40.2 \\
\hline & $H(\mathrm{~m})$ & 19.34 & 3.25 & 6.9 & 25.9 \\
\hline & $d(\mathrm{~cm})$ & 19.09 & 8.81 & 1.1 & 47.0 \\
\hline & $h(\mathrm{~m})$ & 8.36 & 6.40 & 0.3 & 25.0 \\
\hline \multicolumn{6}{|l|}{ Planted species } \\
\hline \multirow{4}{*}{$\begin{array}{l}\text { Dahurian larch } \\
(\mathrm{n}=114 \text { trees })\end{array}$} & $D(\mathrm{~cm})$ & 23.78 & 2.78 & 16.90 & 32.4 \\
\hline & $H(\mathrm{~m})$ & 20.44 & 1.47 & 14.9 & 23.9 \\
\hline & $d(\mathrm{~cm})$ & 16.70 & 7.25 & 1.00 & 43.0 \\
\hline & $h(\mathrm{~m})$ & 9.14 & 6.31 & 0.30 & 23.0 \\
\hline \multirow{4}{*}{$\begin{array}{l}\text { Mongolian pine } \\
(\mathrm{n}=124 \text { trees })\end{array}$} & $D(\mathrm{~cm})$ & 28.50 & 3.34 & 18.6 & 36.6 \\
\hline & $H(\mathrm{~m})$ & 17.99 & 1.06 & 1480 & 22.5 \\
\hline & $d(\mathrm{~cm})$ & 19.67 & 8.82 & 0.80 & 40.2 \\
\hline & $h(\mathrm{~m})$ & 7.95 & 5.55 & 0.30 & 22.0 \\
\hline
\end{tabular}


Table 2. Validation data summary statistics for five commercial tree species in NE China

\begin{tabular}{|c|c|c|c|c|c|}
\hline Natural species & Variable & Mean & SD & Minimum & Maximum \\
\hline \multirow{4}{*}{$\begin{array}{l}\text { Dahurian larch } \\
(\mathrm{n}=27 \text { trees })\end{array}$} & $D(\mathrm{~cm})$ & 25.12 & 4.29 & 19.40 & 36.6 \\
\hline & $H(\mathrm{~m})$ & 19.37 & 1.76 & 14.50 & 22.6 \\
\hline & $d(\mathrm{~cm})$ & 18.23 & 8.50 & 0.60 & 44.2 \\
\hline & $h(\mathrm{~m})$ & 8.22 & 6.15 & 0.30 & 22.0 \\
\hline \multirow{4}{*}{$\begin{array}{l}\text { Korean spruce } \\
(\mathrm{n}=31 \text { trees })\end{array}$} & $D(\mathrm{~cm})$ & 28.85 & 7.66 & 20.40 & 47.1 \\
\hline & $H(\mathrm{~m})$ & 21.40 & 2.76 & 17.70 & 28.2 \\
\hline & $d(\mathrm{~cm})$ & 21.99 & 9.92 & 1.00 & 45.10 \\
\hline & $h(\mathrm{~m})$ & 9.21 & 6.87 & 0.30 & 28.00 \\
\hline \multirow{4}{*}{$\begin{array}{l}\text { Manchurian fir } \\
(\mathrm{n}=36 \text { trees })\end{array}$} & $D(\mathrm{~cm})$ & 22.18 & 3.89 & 10.60 & 30.50 \\
\hline & $H(\mathrm{~m})$ & 18.46 & 2.37 & 10.90 & 22.20 \\
\hline & $d(\mathrm{~cm})$ & 16.93 & 7.44 & 1.10 & 41.90 \\
\hline & $h(\mathrm{~m})$ & 7.88 & 6.01 & 0.30 & 22.00 \\
\hline \multicolumn{6}{|l|}{ Planted species } \\
\hline \multirow{4}{*}{$\begin{array}{l}\text { Dahurian larch } \\
(\mathrm{n}=28 \text { trees })\end{array}$} & $D(\mathrm{~cm})$ & 23.85 & 2.96 & 17.10 & 29.9 \\
\hline & $H(\mathrm{~m})$ & 21.01 & 1.10 & 18.70 & 23.0 \\
\hline & $d(\mathrm{~cm})$ & 16.88 & 7.05 & 1.00 & 36.5 \\
\hline & $h(\mathrm{~m})$ & 9.39 & 6.45 & 0.30 & 22.0 \\
\hline \multirow{4}{*}{$\begin{array}{l}\text { Mongolian pine } \\
\quad(\mathrm{n}=31 \text { trees })\end{array}$} & $D(\mathrm{~cm})$ & 28.61 & 3.66 & 22.00 & 35.0 \\
\hline & $H(\mathrm{~m})$ & 18.43 & 1.14 & 15.80 & 20.8 \\
\hline & $d(\mathrm{~cm})$ & 19.81 & 8.79 & 1.00 & 41.4 \\
\hline & $h(\mathrm{~m})$ & 8.10 & 5.66 & 0.30 & 20.0 \\
\hline
\end{tabular}

\section{Data analysis}

The segmented model of Max and Burkhart (1976) was selected for this analysis based on its good results for many tree species. For example: Appalachian hardwood species in Virginia (Martin, 1981); Pinus taeda in East Texas (Coble and Hilpp, 2006); important conifer species in Turkey (Brooks et al., 2008); Larix kaempferi in South Korea (Doyog et al., 2017); and Betula alnoides in South China (Tang et al., 2017). This model contains three sub-functions, combined in a single equation to represent the top, middle, and bottom stem sections as a cone, paraboloid, and neiloid frustums. The equation is of the form:

$$
\frac{d^{2}}{D^{2}}=b_{1}(Z-1)+b_{2}\left(Z^{2}-1\right)+b_{3}\left(a_{1}-Z\right)^{2} I_{1}+b_{4}\left(a_{2}-Z\right)^{2} I_{2}
$$

where:

$I_{i}=\left\{\begin{array}{ll}1 & Z \leq a_{i} \\ 0 & Z>a_{i}\end{array} \quad i=1,2\right.$

$Z=h / H, h=$ height above the ground to the measurement point (m), $H=$ total tree height (m), $D=$ diameter over bark at breast height $(\mathrm{cm}), d=$ diameter over bark $(\mathrm{cm})$ to the measurement point at height $h, a_{i}=$ joining points to be estimated from the data, and $b_{i}$ are regression coefficients $(i=1,2,3,4)$. 
The volume equation derived through the integration of Max and Burkhart (1976) taper equation is:

$$
V=K D^{2} H\left\{\begin{array}{l}
b_{2} / 3\left(Z_{u}{ }^{3}-Z_{l}^{3}\right)+b_{1} / 2\left(Z_{u}{ }^{2}-Z_{l}^{2}\right)-\left(b_{1}+b_{2}\right)\left(Z_{u}-Z_{l}\right) \\
-b_{3} / 3\left[\left(a_{1}-Z_{u}\right)^{3} J_{1}-\left(a_{1}-Z_{l}\right)^{3} K_{1}\right] \\
-b_{4} / 3\left[\left(a_{2}-Z_{u}\right)^{3} J_{2}-\left(a_{2}-Z_{l}\right)^{3} K_{2}\right]
\end{array}\right\}
$$

where:

$J_{i}=\left\{\begin{array}{ll}1 & Z_{u} \leq a_{i} \\ 0 & Z_{u}>a_{i}\end{array} \quad K_{i}= \begin{cases}1 & Z_{l} \leq a_{i} \\ 0 & Z_{l}>a_{i}\end{cases}\right.$

$K=0.0000785, Z_{l}=h_{l} / H, Z_{u}=h_{u} / H, h_{l}=$ lower height of interest, and $h_{u}=$ upper height of interest. All other variables, as previously defined.

Simultaneous fitting of taper and volume equations was carried out to minimize the diameter and volume prediction errors at the same time. The parameters used in taper and volume equations were the same. Both equations were fitted independently for all species using SAS PROC MODEL (SAS Institute Inc., 2008). Correlated error structure of the data was not considered in the SAS MODEL procedure. Prediction accuracy is slightly influenced even if the error structure is accounted for during the fitting procedure (Kozak, 1997).

\section{Data evaluation}

Three goodness-of-fit statistics, mean absolute bias (MAB), the standard error of the estimate (SEE), and fit index (FI) were tested. The notations for these statistics is as under:

$$
\begin{gathered}
M A B=\frac{\sum_{i=1}^{n}\left|y_{i}-\hat{y}_{i}\right|}{n} \\
S E E=\sqrt{\frac{\sum_{i=1}^{n}\left(y_{i}-\hat{y}_{i}\right)^{2}}{n-k}} \\
F I=1-\left[\frac{\sum_{i=1}^{n}\left(y_{i}-\hat{y}_{i}\right)^{2}}{\sum_{i=1}^{n}\left(y_{i}-\bar{y}_{i}\right)^{2}}\right]
\end{gathered}
$$

where: $y_{i}, \hat{y}_{i}$ stand for the measured and predicted values of the $i^{\text {th }}$ observation, $\bar{y}_{i}$ is the mean of $\hat{y}_{i}, n$ symbolize the total number of observations, and $k$ is the number of model parameters.

\section{Comparison of taper equations among species}

The method of the non-linear extra sum of squares was used to observe whether different taper functions would be needed for different species (Neter et al., 1990). In this method, fitting of full and reduced models $(E q .6)$ is required. It has been implemented to assess the need for separate models for different species (Rivas et al., 2004; Brooks et al., 
2008; Özcelik et al., 2016). The full model constitutes a separate set of parameters for each species, while the reduced model involves the same set of parameters for all species. The full model is attained by expanding all global parameters with a dummy variable and an associated parameter to distinguish the species. The significance of the comparison between full and reduced model is based on $F$-test of the formula:

$$
F=\frac{\left(S S E_{R}-S S E_{F}\right) /\left(d f_{R}-d f_{F}\right)}{S S E_{F} / d f_{F}}
$$

where: $S S E_{R}, S S E_{F}, d f_{R}$, and $d f_{F}$ are the error sum of squares and degrees of freedom for reduced and full models, respectively. The non-linear extra sum of squares follows an $F$-distribution.

Generally, $F$-test (Eq. $\sigma$ ) is believed to be significant, if the $P$-value is below 0.05 . In this case, taper equations are not the same across species, and more tests are required to evaluate the differences. Since any possible combination of the species can produce these differences, the $F$-test of full and reduced models (Eq. O) was carried out for all possible pairs of species.

\section{Results and Discussion}

\section{Taper equations}

Simultaneous fitting was performed to obtain the parameter estimates of taper and volume equations for each species. All parameters were significant at $P<0.0001$. Table 3 highlights the values of MAB, SEE, and FI for the diameters of each species. Above $95 \%$ of the total variation was explained for the prediction of diameter. The estimated SEEs were less than $1.9 \mathrm{~cm}$ for all species. The plots of residuals against the predicted diameters are shown in Fig. 1. Most of the residuals were clustered near the centre of the data points. There was no apparent increase in the error variance with the increase of tree size.

Table 3. Fit statistics for compatible taper and volume equation system for five species

\begin{tabular}{c|ccc|ccc}
\hline \multirow{2}{*}{ Species } & \multicolumn{3}{|c|}{ Taper $(\mathbf{c m})$} & \multicolumn{3}{c}{ Volume $\left(\mathbf{m}^{\mathbf{3}}\right)$} \\
\cline { 2 - 7 } & MAB & SEE & FI & MAB & SEE & FI \\
\hline Dahurian larch & 1.1317 & 1.4083 & 0.9703 & 0.0003 & 0.0025 & 0.9602 \\
Korean spruce & 0.1755 & 1.6977 & 0.9685 & 0.0004 & 0.0042 & 0.9715 \\
Manchurian fir & 0.1646 & 1.8650 & 0.9552 & 0.0004 & 0.0043 & 0.9500 \\
Planted Dahurian larch & 0.0430 & 1.1502 & 0.9749 & 0.0001 & 0.0023 & 0.9681 \\
Planted Mongolian pine & 0.0047 & 1.1392 & 0.9833 & 0.0001 & 0.0027 & 0.9767 \\
\hline
\end{tabular}

Note: MAB, Mean absolute bias; SEE, Standard error of the estimate; FI, Fit index

The performance of the Max and Burkhart equation was also evaluated for different stem sections by using ten relative height $(h / H)$ classes for all species. The statistics of MAB and SEE were calculated for diameter and volume prediction (Tables 4, 5). The SEE values were relatively smaller for Dahurian larch, planted Dahurian larch, and Mongolian pine for larger $(>10 \%)$ relative height classes (Table 4). However, the values of MAB and SEE were higher for Dahurian larch, Korean spruce, and Manchurian fir near the ground. 
Table 4. Diameter ( $\mathrm{cm})$ mean absolute bias $(M A B)$ and standard errors of the estimate (SEE) by relative height (RH) classes for five tree species

\begin{tabular}{|c|c|c|c|c|c|c|c|c|c|c|c|c|c|c|c|}
\hline \multirow{2}{*}{$\mathbf{R H}$} & \multicolumn{3}{|c|}{ Dahurian larch } & \multicolumn{3}{|c|}{ Korean spruce } & \multicolumn{3}{|c|}{ Manchurian fir } & \multicolumn{3}{|c|}{ Planted Dahurian larch } & \multicolumn{3}{|c|}{ Planted Mongolian fir } \\
\hline & $\mathbf{n}$ & MAB & SEE & n & MAB & SEE & $\mathbf{n}$ & MAB & SEE & n & MAB & SEE & $\mathbf{n}$ & MAB & SEE \\
\hline $0.0-0.1$ & 642 & 0.5442 & 2.0017 & 689 & 0.3284 & 1.9774 & 440 & 0.2941 & 1.5689 & 528 & 0.1550 & 1.1253 & 498 & -0.0693 & 0.9040 \\
\hline $0.1-0.2$ & 227 & -0.1586 & 0.7675 & 266 & 0.1308 & 1.4880 & 160 & 0.1065 & 0.9463 & 227 & 0.0247 & 0.7524 & 246 & 0.1686 & 0.7904 \\
\hline $0.2-0.3$ & 228 & -0.2516 & 0.9290 & 257 & 0.0030 & 1.5774 & 155 & 0.1049 & 1.1418 & 228 & -0.1729 & 0.9097 & 238 & -0.1638 & 0.9252 \\
\hline $0.3-0.4$ & 223 & -0.1140 & 1.0099 & 258 & 0.1612 & 1.5811 & 151 & 0.1432 & 1.3677 & 223 & -0.1195 & 1.0101 & 208 & -0.2388 & 0.9750 \\
\hline $0.4-0.5$ & 233 & 0.0659 & & 260 & 0.2664 & 1.5534 & 162 & 0.2375 & 1.6060 & 233 & -0.0005 & 1.1031 & 230 & -0.1508 & 1.0279 \\
\hline $0.5-0.6$ & 234 & 0.1914 & 1.2392 & 258 & 0.3375 & 1.6261 & 152 & 0.1960 & 1.8235 & 234 & 0.0931 & 1.2281 & 225 & 0.2017 & 1.1664 \\
\hline $0.6-0.7$ & 235 & 0.2485 & 1.2696 & 261 & 0.3640 & 1.7660 & 159 & 0.1229 & 2.1620 & 235 & 0.1608 & 1.2552 & 227 & 0.4194 & 1.3843 \\
\hline $0.7-0.8$ & 226 & 0.1364 & 1.4071 & 252 & 0.2472 & 1.9981 & 154 & 0.0052 & 2.4983 & 226 & 0.1261 & 1.4024 & 206 & 0.1331 & 1.6222 \\
\hline $0.8-0.9$ & 230 & -0.1811 & 1.3132 & 263 & 0.0540 & 2.2425 & 155 & -0.0799 & 2.6593 & 230 & -0.0897 & 1.3020 & 221 & -0.2381 & 1.5301 \\
\hline $0.9-1.0$ & 226 & 0.0794 & 1.3449 & 246 & 0.1880 & 2.8647 & 165 & 0.2691 & 2.5956 & 226 & 0.1063 & 1.3442 & 217 & 0.0584 & 1.1705 \\
\hline All & 2704 & 0.1317 & 1.4083 & 3010 & 0.2251 & 1.9064 & 1853 & 0.1646 & 1.8650 & 2590 & 0.0430 & 1.1502 & 2516 & 0.0047 & 1.1392 \\
\hline
\end{tabular}

Note: The last row represents the overall mean of MAB and SEE

Table 5. Volume $\left(\mathrm{m}^{3}\right)$ mean absolute bias (MAB) and standard errors of the estimate (SEE) by relative height (RH) classes for five tree species

\begin{tabular}{|c|c|c|c|c|c|c|c|c|c|c|c|c|c|c|c|}
\hline \multirow{2}{*}{ RH } & \multicolumn{3}{|c|}{ Dahurian larch } & \multicolumn{3}{|c|}{ Korean spruce } & \multicolumn{3}{|c|}{ Manchurian fir } & \multicolumn{3}{|c|}{ Planted Dahurian larch } & \multicolumn{3}{|c|}{ Planted Mongolian fir } \\
\hline & $\mathbf{n}$ & MAB & SEE & $\mathbf{n}$ & MAB & SEE & n & MAB & SEE & $\mathbf{n}$ & MAB & SEE & $\mathbf{n}$ & МАВ & SEE \\
\hline $0.0-0.1$ & 642 & 0.0009 & 0.0025 & 689 & 0.0008 & 0.0037 & 440 & 0.0005 & 0.0022 & 528 & 0.0004 & 0.0016 & 498 & -0.0001 & 0.0013 \\
\hline $0.1-0.2$ & 227 & -0.0006 & 0.0026 & 266 & 0.0000 & 0.0072 & 160 & 0.0000 & 0.0040 & 227 & -0.0001 & 0.0025 & 246 & 0.0007 & 0.0031 \\
\hline $0.2-0.3$ & 228 & -0.0007 & 0.0030 & 257 & -0.0002 & 0.0071 & 155 & 0.0003 & 0.0045 & 228 & -0.0005 & 0.0029 & 238 & -0.0007 & 0.0035 \\
\hline $0.3-0.4$ & 223 & -0.0001 & 0.0029 & 258 & 0.0007 & 0.0066 & 151 & 0.0006 & 0.0052 & 223 & -0.0002 & 0.0029 & 208 & -0.0007 & 0.0034 \\
\hline $0.4-0.5$ & 233 & 0.0004 & 0.0031 & 260 & 0.0009 & 0.0060 & 162 & 0.0007 & 0.0055 & 233 & 0.0002 & 0.0030 & 230 & -0.0002 & 0.0033 \\
\hline $0.5-0.6$ & 234 & 0.0006 & 0.0030 & 258 & 0.0009 & 0.0057 & 152 & 0.0006 & 0.0056 & 234 & 0.0004 & 0.0030 & 225 & 0.0008 & 0.0035 \\
\hline $0.6-0.7$ & 235 & 0.0006 & 0.0026 & 261 & 0.0010 & 0.0054 & 159 & 0.0004 & 0.0058 & 235 & 0.0005 & 0.0026 & 227 & 0.0011 & 0.0036 \\
\hline $0.7-0.8$ & 226 & 0.0002 & 0.0022 & 252 & 0.0004 & 0.0049 & 154 & 0.0003 & 0.0053 & 226 & 0.0003 & 0.0022 & 206 & 0.0002 & 0.0028 \\
\hline $0.8-0.9$ & 230 & 0.0000 & 0.0014 & 263 & 0.0001 & 0.0042 & 155 & 0.0003 & 0.0039 & 230 & 0.0001 & 0.0014 & 221 & 0.0000 & 0.0016 \\
\hline $0.9-1.0$ & 226 & 0.0001 & 0.0007 & 246 & 0.0002 & 0.0024 & 165 & 0.0002 & 0.0019 & 226 & 0.0001 & 0.0007 & 217 & 0.0001 & 0.0005 \\
\hline All & 2704 & 0.0003 & 0.0025 & 3010 & 0.0005 & 0.0054 & 1853 & 0.0004 & 0.0043 & 2590 & 0.0001 & 0.0023 & 2516 & 0.0001 & 0.0027 \\
\hline
\end{tabular}


As a whole, the standard errors of the estimates were higher for $0-10 \%$ and above $60 \%$ relative heights in all species. These specific relative heights are connected with the butt swell and the point corresponding to the base of the live crown for the sampled trees (Jiang et al., 2005). Previously, this trend was also noticed for other species (Özcelik and Brooks, 2012; Özcelik and Crecente-Campo, 2016).

\section{Volume equations}

The values of MAB, SEE, and FI for total stem volume are given in Table 3. Above 96\% of the total variance of the volume was explained in all species except Manchurian fir, where $95 \%$ of the total variance was indicated. The value of SEE was less than $0.005 \mathrm{~m}^{3}$ for all species. The proposed equation was also examined for volume estimation of different stem sections (Table 5). The range of SEE was $0.0005 \mathrm{~m}^{3}$ to $0.0072 \mathrm{~m}^{3}$ depending upon the species and relative height classes. As compared to Korean spruce and Manchurian fir, the average error was lower and almost the same for Dahurian larch and planted species. Most of the residuals were accumulated around zero, showing that the predictions were not biased (Fig. 1).

The average errors (SEE) in diameter and volume predictions correspond to the previous evaluations of the Max and Burkhart equation. Brooks et al. (2008) and Özcelik and Brooks (2012) reported the maximum SEE of $2.83 \mathrm{~cm}$ and $2.53 \mathrm{~cm}$, respectively, in diameter prediction by relative heights for major commercial trees in Turkey. In our case, the SEE was $2.86 \mathrm{~cm}$ for this variable. However, the standard errors were lower for the estimates of total stem diameter, total volume, and sectional volume in this study. Doyog et al. (2017) recorded the SEE in diameter predictions of Japanese larch as $1.74 \mathrm{~cm}$ for total stem and $2.38 \mathrm{~cm}$ for different sections, lower than this study. Conversely, the values for volume estimates were higher compared with our results. Interestingly, the analysis by Jiang et al. (2005) showed a similar tendency for yellow poplar in West Virginia.

A comparison was also carried out between total volume estimates by the proposed model and existing volume tables for the species analysed (Table 6). Total volume predictions based on the validation data were better than the estimates of volume tables in terms of the MAB and SEE for all species. Particularly for Korean spruce, Manchurian fir, and planted Dahurian larch, the SEE was 30\%, 33\%, and 24\% less than the volume tables. The plots of total volume residuals for the proposed equation and the prevailing volume tables exhibited higher prediction errors in volume tables for all species (Fig. 2). In general, the predictions were larger for bigger trees. This model not only provides a better prediction of total volume but can also predict volumes to any specific height. The available volume tables are devoid of this useful characteristic. Finally, the suggested taper and volume equations were refitted to the combined data (fitting and validation datasets). Species wise parameter estimates are depicted in Table 7.

Fitting results with the combined data for full and reduced models based on the proposed equation (6) are shown in Table 8. The $F$-statistic computed by equation (6) was 241.51 , which indicates a probability of Type I error of less than 0.0001 . Thus, taper equations were not the same for different species. $F$-tests were exercised for each possible pair of the species to detect the differences. All of the ten possible paired comparisons produced significant $F$-values, indicating the nonconformity of one equation for different species. Therefore, separate parameter estimates by species and stand origins (planted vs. natural) were developed.

The Max and Burkhart equation has delivered reliable results in many studies (Martin, 1981; Coble and Hilpp, 2006; Brooks et al., 2008; Özcelik and Brooks, 2012; Doyog et 
al., 2017; Tang et al., 2017). Among five equations, this model provided the most consistent results in predicting the diameter, height, and volume of Appalachian tree species in Virginia (Martin, 1981). Coble and Hilpp (2006) recommended it for diameter and volume estimation of loblolly pine in East Texas. Out of 28 taper equations, the Max and Burkhart equation was the best-segmented model for Betula alnoides in South China (Tang et al., 2017). It was recommended for major commercial tree species of Turkey and Japanese larch in South Korea (Brooks et al., 2008; Doyog et al., 2017).

Table 6. Comparison of total volume MAB and SEE for the proposed Max and Burkhart model and existing total stem volume table estimates for five commercial species

\begin{tabular}{c|c|c}
\hline Species and Models & MAB $\left(\mathbf{m}^{\mathbf{3}}\right)$ & SEE $\left.\mathbf{( m}^{\mathbf{3}}\right)$ \\
\hline Natural species & & \\
\hline Dahurian larch & & 0.0515 \\
Max and Burkhart model & -0.0134 & 0.0577 \\
Existing volume table & 0.0427 & 0.0583 \\
Korean spruce & 0.0249 & 0.1926 \\
\hline Max and Burkhart model & 0.1506 & 0.0313 \\
Existing volume table & & 0.0955 \\
\hline Manchurian fir & 0.0177 & \\
\hline Max and Burkhart model & 0.0821 & 0.0354 \\
Existing volume table & & \\
\hline Planted species & -0.0109 & 0.1493 \\
\hline Dahurian larch & 0.1442 & 0.0689 \\
\hline Max and Burkhart model & & 0.1023 \\
Existing volume table & -0.0393 & \\
\hline Mongolian pine & 0.0765 &
\end{tabular}
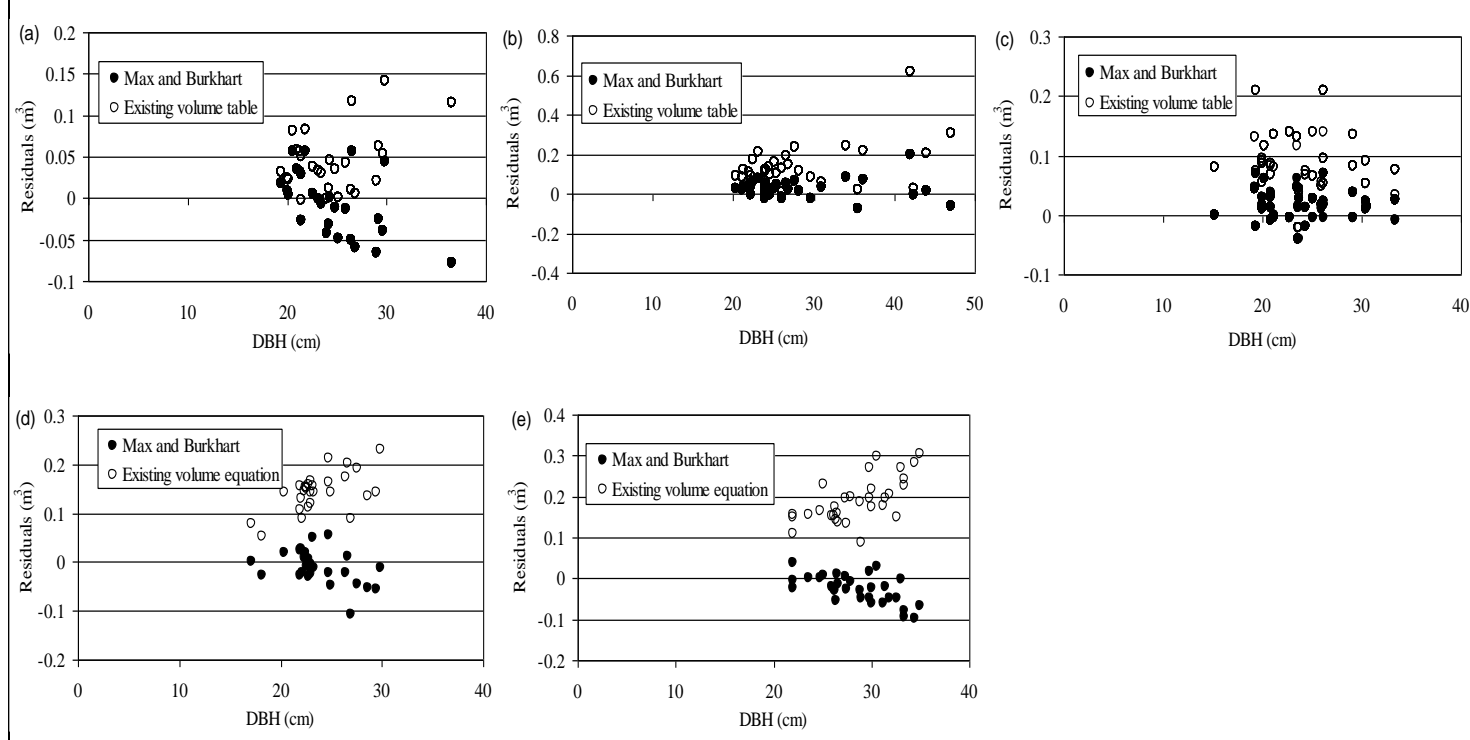

Figure 2. Total volume residuals (validation data) for the proposed Max and Burkhart volume model and the existing total volume tables for (a) Dahurian larch, (b) Korean spruce, (c) Manchurian fir, (d) Planted Dahurian larch, and (e) Planted Mongolian pine, respectively. Note: Planted Dahurian larch: $V=0.00013884773(\mathrm{dbh})^{2.43569275}$; Planted Mongolian pine:

$$
V=0.00016511358(d b h)^{2.2206393}
$$


Table 7. Parameter estimates for Max and Burkhart model for five species based on all sample data

\begin{tabular}{c|c|c|c|c|c}
\hline Parameter & $\begin{array}{c}\text { Dahurian } \\
\text { larch }\end{array}$ & $\begin{array}{c}\text { Korean } \\
\text { spruce }\end{array}$ & $\begin{array}{c}\text { Manchurian } \\
\text { fir }\end{array}$ & $\begin{array}{c}\text { Planted Dahurian } \\
\text { larch }\end{array}$ & $\begin{array}{c}\text { Planted } \\
\text { Mongolian pine }\end{array}$ \\
\hline$b_{1}$ & -3.7441 & -2.3407 & -3.1631 & -4.8482 & -5.2379 \\
$b_{2}$ & 1.7342 & 0.6818 & 1.1547 & 2.2595 & 2.5409 \\
$b_{3}$ & -1.7395 & -0.9794 & -1.4586 & -2.2460 & -2.5964 \\
$b_{4}$ & 91.390 & 147.859 & 117.821 & 618.454 & 73.603 \\
$a_{1}$ & 0.7752 & 0.8460 & 0.8303 & 0.8339 & 0.8118 \\
$a_{2}$ & 0.0936 & 0.0714 & 0.0715 & 0.0441 & 0.0923 \\
\hline
\end{tabular}

Table 8. F-test for Full and Reduced models using Max and Burkhart model for the species analysed

\begin{tabular}{c|c|cc|cc|c|c|c}
\hline \multirow{2}{*}{ Model } & \multirow{2}{*}{$\mathbf{n}$} & \multicolumn{2}{|c|}{ Full Model } & \multicolumn{2}{|c|}{ Reduced Model } & \multirow{2}{*}{$\mathbf{d f}_{\mathbf{R}-\mathbf{d f}_{\mathbf{F}}}$} & \multirow{F}{*}{-value } & \multirow{2}{*}{$\boldsymbol{P}$-value } \\
\cline { 3 - 8 } & & $\mathbf{S S E}_{\mathbf{F}}$ & $\mathbf{d f}_{\mathbf{F}}$ & $\mathbf{S S E}_{\mathbf{R}}$ & $\mathbf{d f}_{\mathbf{R}}$ & & & \\
\hline Combined & 13668 & 35307.21 & 13643 & 47182.50 & 13662 & 19 & 241.51 & $<0.0000$ \\
DL-KS & 5395 & 17792.10 & 5383 & 22788.42 & 5389 & 6 & 251.93 & $<0.0000$ \\
DL-MF & 5552 & 17821.21 & 5540 & 23289.14 & 5546 & 6 & 283.29 & $<0.0000$ \\
DL-PDL & 4975 & 10359.23 & 4963 & 10833.99 & 4969 & 6 & 37.90 & $<0.0000$ \\
DL-PMP & 4901 & 10186.86 & 4889 & 10869.98 & 4895 & 6 & 54.64 & $<0.0000$ \\
KS-MF & 6177 & 21703.96 & 6165 & 22053.46 & 6171 & 6 & 16.54 & $<0.0000$ \\
KS-PDL & 5600 & 14265.63 & 5588 & 16570.82 & 5594 & 6 & 150.49 & $<0.0000$ \\
KS-PMP & 5526 & 16105.30 & 5514 & 19665.18 & 5520 & 6 & 203.13 & $<0.0000$ \\
MF-PDL & 5757 & 14271.08 & 5745 & 16973.27 & 5751 & 6 & 181.29 & $<0.0000$ \\
MF-PMP & 5683 & 16134.41 & 5671 & 19841.96 & 5677 & 6 & 217.19 & $<0.0000$ \\
PDL-PMP & 5106 & 6660.40 & 5094 & 7169.40 & 5100 & 6 & 64.88 & $<0.0000$ \\
\hline
\end{tabular}

Note: DL, Dahurian larch; KS, Korean spruce; MF, Manchurian fir; PDL, Planted Dahurian larch; and PMP, Planted Mongolian pine. F-values were calculated by equation (6). $\mathrm{SSE}_{\mathrm{F}}, \mathrm{df}_{\mathrm{F}}, \mathrm{SSE}_{\mathrm{R}}$, and $\mathrm{df}_{\mathrm{R}}$ are the sum of squared errors and the degrees of freedom

\section{Conclusions}

This study presents an initial attempt to develop compatible taper and volume equations for Dahurian larch, Korean spruce, Manchurian Fir, and planted Dahurian larch and Mongolian pine in NE China. Fitting of the taper and volume equations was performed simultaneously to confirm the numeric consistency. The model of Max and Burkhart behaved consistently in terms of fit statistics, sectional performance, and graphical interpretation for diameter and volume estimates. The prediction of total stem volume by the proposed equation was superior to volume tables in vogue for the species under study. As an additional attribute, this model can also be applied in the field for the estimation of stem volume to any specific height.

Acknowledgements. We would like to acknowledge the efforts of all investigators, who collected the data for this study. This research was financially supported by the National Natural Science Foundation of China (31570624), Applied Technology Research and Development Plan Project of Heilongjiang Province (GA19C006), and Fundamental Research Funds for Central Universities (2572019CP15). 


\section{REFERENCES}

[1] Bailey, R. L. (1995): Upper stem volumes from stem analysis data: an overlapping bolts method. - Canadian Journal of Forest Research 25(1): 170-173.

[2] Barrio Anta, M., Diéguez-Aranda, U., Castedo-Dorado, F., Álvarez González, J. G., von Gadow, K. (2007): Merchantable volume system for pedunculate oak in northwestern Spain. - Annals of Forest Science 64(5): 511-520.

[3] Brooks, J. R., Jiang, L., Ozcelik, R. (2008): Compatible stem volume and taper equations for Brutian pine, Cedar of Lebanon, and Cilicica fir in Turkey. - Forest Ecology and Management 256(1-2): 147-151.

[4] Burger, D., Shidong, Z. (1988): An introductory comparison of forest ecological conditions in northeast China and Ontario, Canada. - The Forestry Chronicle 64(2): 105-115.

[5] Burkhart, H., Tomé, M. (2012): Modeling forest trees and stands. - Springer, Dordrecht.

[6] Burkhart, H., Avery, T. E., Bullock, B. P. (2019): Forest measurements. - Waveland Press, Long Grove, IL.

[7] Chinese Ministry of Forestry (2009): Forest resources of China-The seventh national forest resource inventory. - Chinese Ministry of Forestry, Beijing (in Chinese).

[8] Coble, D. W., Hilpp, K. (2006): Compatible cubic-foot stem volume and upper-stem diameter equations for semi-intensive plantation grown loblolly pine trees in East Texas. Southern Journal of Applied Forestry 30(3): 132-141.

[9] Crecente-Campo, F., Rojo Alboreca, A., Diéguez-Aranda, U. (2009): A merchantable volume system for Pinus sylvestris L. in the major mountain ranges of Spain. - Annals of Forest Science 66(8): 1-12.

[10] Deleuze, C., Houllier, F. (2002): A flexible radial increment taper equation derived from a process-based carbon partitioning model. - Annals of Forest Science 59(2): 141-154.

[11] Demaerschalk, J. P. (1972): Converting volume equations to compatible taper equations. Forest Science 18(3): 241-245.

[12] Diéguez-Aranda, U., Castedo-Dorado, F., Álvarez-González, J. G., Rojo, A. (2006): Compatible taper function for Scots pine plantations in northwestern Spain. - Canadian Journal of Forest Research 36(5): 1190-1205.

[13] Dong, L., Zhang, L., Li, F. (2014): A compatible system of biomass equations for three conifer species in Northeast China. - Forest Ecology and Management 329: 306-317.

[14] Doyog, N. D., Lee, Y. J., Lee, S. J., Kang, J. T., Kim, S. Y. (2017): Compatible taper and stem volume equations for Larix kaempferi (Japanese larch) species of South Korea. Journal of Mountain Science 14(7): 1341-1349.

[15] Fang, Z., Bailey, R. L. (1999): Compatible volume and taper models with coefficients for tropical species on Hainan island in southern China. - Forest Science 45(1): 85-100.

[16] FAO (2015): Global forest resources assessment. - UN Food and Agriculture Organization, Rome, Italy. Available at: http://www. fao.org/3/a-i4808e.pdf. Accessed 6 December 2019.

[17] Heidarsson, L., Pukkala, T. (2011): Taper functions for lodgepole pine (Pinus contorta) and Siberian larch (Larix sibirica) in Iceland. - Icelandic Agricultural Sciences 24(3): 311.

[18] Heilongjiang Forest Bureau (1981): Standing tree volume table. - Publication No. 86/81, Heilongjiang, China (in Chinese).

[19] Ikonen, V. P., Kellomäki, S., Peltola, H. (2003): Linking tree stem properties of Scots pine (Pinus sylvestris L.) to sawn timber properties through simulated sawing. - Forest Ecology and Management 174(1): 251-263.

[20] Jia, Z., Qu, G. (2011): China national progress report to the UNFF secretariat on the implementation of NLBI and other relevant resolutions. - International Forestry Cooperation Centre, State Forestry Administration of P. R. China. Available at: http://www.unece.1su.edu/certificate_eccos/documents/2013Mar/ce13_07.pdf.

[21] Jia, B., Zhou, G. (2018): Growth characteristics of natural and planted Dahurian larch in northeast China. - Earth System Science Data 10(2): 893-898. 
[22] Jiang, L., Brooks, J. R., Wang, J. (2005): Compatible taper and volume equations for yellow-poplar in West Virginia. - Forest Ecology and Management 213(1): 399-409.

[23] Jiang, L., Liu, R. (2011): Segmented taper equations with crown ratio and stand density for Dahurian Larch (Larix gmelinii) in Northeastern China. - Journal of Forestry Research 22(3): 347-352.

[24] Kozak, A., Smith, J. (1993): Standards for evaluating taper estimating systems. - The Forestry Chronicle 69(4): 438-444.

[25] Kozak, A. (1997): Effects of multicollinearity and autocorrelation on the variable-exponent taper functions. - Canadian Journal of Forest Research 27(5): 619-629.

[26] Kozak, A. (2004): My last words on taper equations. - The Forestry Chronicle 80(4): 507515.

[27] Laasasenaho, J. (1982): Taper curve and volume functions for pine, spruce and birch. Communicationes Instituti Forestalis Fenniae 108: 74.

[28] Li, R., Weiskittel, A. R. (2010): Comparison of model forms for estimating stem taper and volume in the primary conifer species of the North American Acadian Region. - Annals of Forest Science 67(3): 302-302.

[29] Lumbres, R. I. C., Abino, A. C., Pampolina, N. M., Calora, F. G., Lee, Y. J. (2016): Comparison of stem taper models for the four tropical tree species in Mount Makiling, Philippines. - Journal of Mountain Science 13(3): 536-545.

[30] Ma, J., Hu, Y., Bu, R., Chang, Y., Deng, H., Qin, Q. (2014): Predicting impacts of climate change on the aboveground carbon sequestration rate of a temperate forest in northeastern China. - PLOS ONE 9(4): 1-15.

[31] Martin, A. J. (1981): Taper and volume equations for selected Appalachian hardwood species. - USDA Forest Service NE-490, Northeastern Forest Experiment Station, Broomall, PA.

[32] Max, T. A., Burkhart, H. E. (1976): Segmented polynomial regression applied to taper equations. - Forest Science 22(3): 283-289.

[33] Neter, J., Wasserman, W., Kutner, M. H. (1990): Applied linear statistical models: Regression, analysis of variance, and experimental designs. - Irwin, Boston, MA.

[34] Newnham, R. (1988): A variable form taper function. - Canadian Forest Service, Pettawa National Forest Institute Rep. PI-X-83, Chalk River, ON.

[35] Özcelik, R., Brooks, J. R. (2012): Compatible volume and taper models for economically important tree species of Turkey. - Annals of Forest Science 69(1): 105-118.

[36] Özcelik, R., Göceri, M. F. (2015): Compatible merchantable stem volume and taper equations for Eucalyptus plantations in the eastern Mediterranean region of Turkey. Turkish Journal of Agriculture and Forestry 39(6): 851-863.

[37] Özcelik, R., Crecente-Campo, F. (2016): Stem taper equations for estimating merchantable volume of Lebanon cedar trees in the Taurus Mountains, Southern Turkey. - Forest Science 62(1): 78-91.

[38] Özcelik, R., Karatepe, Y., Gürlevik, N., Canellas, I., Crecente-Campo, F. (2016): Development of ecoregion-based merchantable volume systems for Pinus brutia Ten. and Pinus nigra Arnold. in southern Turkey. - Journal of Forestry Research 27(1): 101-117.

[39] Özcelik, R., Dirican, O. (2017): Individual taper models for natural cedar and Taurus fir mixed stands of Bucak Region, Turkey. - Journal of the Faculty of Forestry Istanbul University 67(2): 243-261.

[40] Payn, T., Carnus, J. M., Freer-Smith, P., Kimberley, M., Kollert, W., Liu, S., Orazio, C., Rodriguez, L., Silva, L. N., Wingfield, M. J. (2015): Changes in planted forests and future global implications. - Forest Ecology and Management 352: 57-67.

[41] Rivas, J. J. C., Gonzalez, J. G. L., Gonzalez, A. D. R., von Gadow, K. (2004): Compatible height and site index models for five pine species in El Salto, Durango (Mexico). - Forest Ecology and Management 201(2-3): 145-160. 
[42] Rojo, A., Perales, X., Sanchez-Rodriguez, F., Alvarez-Gonzalez, J. G., von Gadow, K. (2005): Stem taper functions for maritime pine (Pinus pinaster Ait.) in Galicia (Northwestern Spain). - European Journal of Forest Research 124(3): 177-186.

[43] Sakici, O. E., Misir, N., Yavuz, H., Misir, M. (2008): Stem taper functions for Abies nordmanniana subsp. bornmulleriana in Turkey. - Scandinavian Journal of Forest Research 23(6): 522-533.

[44] Sakici, O. E., Ozdemir, G. (2018): Stem taper estimations with artificial neural networks for mixed Oriental beech and Kazdagi fir stands in Karabük region, Turkey. - CERNE 24(4): 439-451.

[45] SAS Institute, Inc. (2008): SAS/ STAT ${ }^{\circledR} 9.2$ user's guide. - SAS Institute, Inc., Cary, NC.

[46] Schröder, T., Costa, E. A., Valério, A. F., dos Santos Lisboa, G. (2014): Taper equations for Pinus elliottii Engelm. in southern Paraná, Brazil. - Forest Science 61(2): 311-319.

[47] Tan, K., Piao, S., Peng, C., Fang, J. (2007): Satellite-based estimation of biomass carbon stocks for northeast China's forests between 1982 and 1999. - Forest Ecology and Management 240(1): 114-121.

[48] Tang, C., Wang, C. S., Pang, S. J., Zhao, Z. G., Guo, J. J., Lei, Y. C., Zeng, J. (2017): Stem taper equations for Betula alnoides in South China. - Journal of Tropical Forest Science 29(1): 80-92.

[49] Wang, F., Letort, V., Lu, Q., Bai, X., Guo, Y., de Reffye, P., Li, B. (2012): A functional and structural Mongolian Scots pine (Pinus sylvestris var. mongolica) model integrating architecture, biomass and effects of precipitation. - PLOS ONE 7(8): 1-13.

[50] Wang, X., Wang, S., Dai, L. (2018): Estimating and mapping forest biomass in northeast China using joint forest resources inventory and remote sensing data. - Journal of Forestry Research 29(3): 797-811.

[51] Westfall, J. A., Scott, C. T. (2010): Taper models for commercial tree species in the northeastern United States. - Forest Science 56(6): 515-528.

[52] Younger, N., Temesgen, H., Garber, S. (2008): Taper and volume responses of Douglasfir to sulfur treatments for control of swiss needle cast in the coast range of Oregon. Western Journal of Applied Forestry 23(3): 142-148.

[53] Zeng, W., Tomppo, E., Healey, S. P., Gadow, K. V. (2015): The national forest inventory in China: History-results-international context. - Forest Ecosystems 2(1): 1-16.

[54] Zhang, X., Liu, X., Zhang, Q., Zeng, X., Xu, G., Wu, G., Wang, W. (2018): Speciesspecific tree growth and intrinsic water-use efficiency of Dahurian larch (Larix gmelinii) and Mongolian pine (Pinus sylvestris var. mongolica) growing in a boreal permafrost region of the Greater Hinggan Mountains, Northeastern China. - Agricultural and Forest Meteorology 248: 145-155.

[55] Zhang, X., Zhang, X., Han, H., Shi, Z., Yang, X. (2019): Biomass accumulation and carbon sequestration in an age-sequence of Mongolian pine plantations in Horqin Sandy Land, China. - Forests 10(2): 1-18.

[56] Zhou, G., Wang, Y., Jiang, Y., Yang, Z. (2002): Estimating biomass and net primary production from forest inventory data: A case study of China's Larix forests. - Forest Ecology and Management 169(1): 149-157. 